UCB, Speakers bureau: Consultancy / speaker fees from: Abbvie, BMS, Celgene, Lilly, MSD, Novartis, Pfizer, Roche, UCB, Susanne Lüders: None declared, Judith Rademacher: None declared, Hildrun Haibel Consultant of: Abbvie, Jansen, MSD, and Novartis, Speakers bureau: Abbvie, Jansen, MSD, and Novartis, Maryna Verba: None declared, Joachim Sieper Consultant of: AbbVie, Boehringer Ingelheim, Eli Lilly and Company, Janssen, Merck, Novartis, Pfizer, Roche, and UCB Pharma, Speakers bureau: AbbVie, Boehringer Ingelheim, Eli Lilly and Company, Janssen, Merck, Novartis, Pfizer, Roche, and UCB Pharma, Elena Sonnenberg: None declared, Michael Schumann: None declared, Lea Isabell Kredel: None declared, Britta Siegmund Consultant of: Abbvie, Boehringer, Celgene, Falk, Janssen, Lilly, Pfizer, Prometheus, Takeda, Speakers bureau: Abbvie, CED Service $\mathrm{GmbH}$, Falk, Ferring, Janssen, Novartis, Takeda (BS served as representative of the Charité), Denis Poddubnyy Grant/research support from: AbbVie, MSD, Novartis, and Pfizer, Consultant of: AbbVie, Bristol-Myers Squibb, Eli Lilly, MSD, Novartis, Pfizer, Roche, UCB, Speakers bureau: AbbVie, Bristol-Myers Squibb, Eli Lilly, MSD, Novartis, Pfizer, Roche, UCB

DOI: 10.1136/annrheumdis-2020-eular.4178

\section{FRI0324 NO RADIOGRAPHIC SACROILIITIS PROGRESSION OVER 6 YEARS IN PATIENTS WITH EARLY SPONDYLOARTHRITIS FROM THE ESPERANZA COHORT}

C. Tornero ${ }^{1}$, M. D. C. Castro Villegas ${ }^{2}$, X. Juanola-Roura ${ }^{3}$, M. L. GarcíaVivar $^{4}$, C. Fernández-Carballido ${ }^{5}$, J. F. Garcia Llorente ${ }^{6}$, B. Joven-Ibáñez ${ }^{7}$ E. Galindez ${ }^{4,8}$, C. Urrego-Laurín ${ }^{9}$, E. De Miguel ${ }^{1}$ on behalf of Esperanza Working Group. ${ }^{1}$ Hospital Universitario La Paz, Rheumatology, Madrid, Spain ${ }^{2}$ Hospital Reina Sofía, Rheumatology, Córdoba, Spain; ${ }^{3}$ Hospital Universitario de Bellvitge, Rheumatology, Madrid, Spain; ${ }^{4}$ Hospital Universitario Basurto, Rheumatology, Bilbao, Spain; ${ }^{5}$ Hospital Universitario San Juan, Rheumatology, Alicante, Spain; ${ }^{6}$ Hospital de Galdakao, Rheumatology, Bilbao, Spain; ${ }^{7}$ Hospital 12 de Octubre, Rheumatology, Madrid, Spain; ${ }^{8}$ Hospital Universitario de Basurto, Bilbao, Spain; ${ }^{9}$ Hospital Universitario Moncloa, Rheumatology, Madrid, Spain

Background: Longitudinal studies about the change from non-radiographic axial Spondyloarthritis (nr-axSpA) to r-axSpA (radiographic axial Spondyloarthritis) are scarce but show a $9-10 \%$ progression rate over 2 years (1-2) and a $24 \%$ progression rate over 10 years in another study (3). However, in early cohorts such as DESIR, this only represents a $5 \%$ over 5 years (4).

Objectives: The aim of this study was to know the rate of progression from nr-axSpA to r-axSpA over 6 years in the early Esperanza cohort.

Methods: This study included 94 patients of the Spanish early spondyloarthritis (SpA) Esperanza cohort, 60 fulfilled the ASAS classification criteria for SpA. Every patient had a baseline and a six years sacroiliac $X$-ray. Nine readers, blinded for the diagnosis, participated in the reliability exercise, all of them experienced rheumatologists and members of the Spanish spondyloarthritis working group (GRESSER). Patients with SpA were classified as having r-axSpA, at baseline or after 6 years of follow-up, if they fulfilled the radiographic item of the modified New York criteria ( $\mathrm{mNY}$ ) (presence of radiographic changes in the sacroiliac joints -SIJ- of at least grade II bilaterally or grade III or IV unilaterally). The gold standard of SIJ X-Ray was the categorical opinion of at least five of the expert readers. For the statistical analysis, the Chi-square and Kappa tests were performed.

Results: Demographic data of the $\mathrm{SpA}$ patients were: mean age $33.4 \pm 7.5$ years; $37(61.7 \%)$ male; mean CRP $6.4 \pm 6.5 \mathrm{mg} / \mathrm{dl}$ and ESR $10.3 \pm 10.6$. Present smokers $30.6 \%$; and past smokers $16.3 \%$. HLA-B27 (+) 56.7\%. Regarding the presence of X-Ray sacroilitis: 20 patients had baseline sacroilitis and 18 at the final visit; 11 had sacroiliitis at both baseline and final visits; 9 patients changed from baseline sacroiliitis to no-sacroiliitis and 7 changed from baseline no-sacroiliitis to sacroiliitis at the 6 year visit. The reliability of the readers was fair with a mean inter-reader kappa test of 0.375 (range $0.146-0.652$ ) and a mean agreement of $73.7 \%$ (range $58.7 \%$ - 90\%).

Conclusion: In this group of patients with early SpA no progression from nr-axSpA to r-axSpA over 6 years was observed. It appears that early diagnosis and standard treatment seem to reduce SIJ radiographic progression.

References:

[1] Poddubnyy D, Rudwaleit M, Haibel H, et al. Rates and predictors of radiographic sacroiliitis progression over 2 years in patients with axial spondyloarthritis. Ann Rheum Dis 2011;70:1369-74.

[2] Sampaio-Barros PD, Conde RA, Donadi EA, et al. Undifferentiated spondyloarthropathies in Brazilians: importance of HLA-B27 and the B7-CREG alleles in characterization and disease progression. J Rheumatol 2003;30:2632-7.

[3] Sampaio-Barros PD, Bortoluzzo AB, Conde RA, et al. Undifferentiated spondyloarthritis: a longterm followup. J Rheumatol 2010;37:1195-9.

[4] Dougados M, et al. Ann Rheum Dis 2017;76:1823-1828.

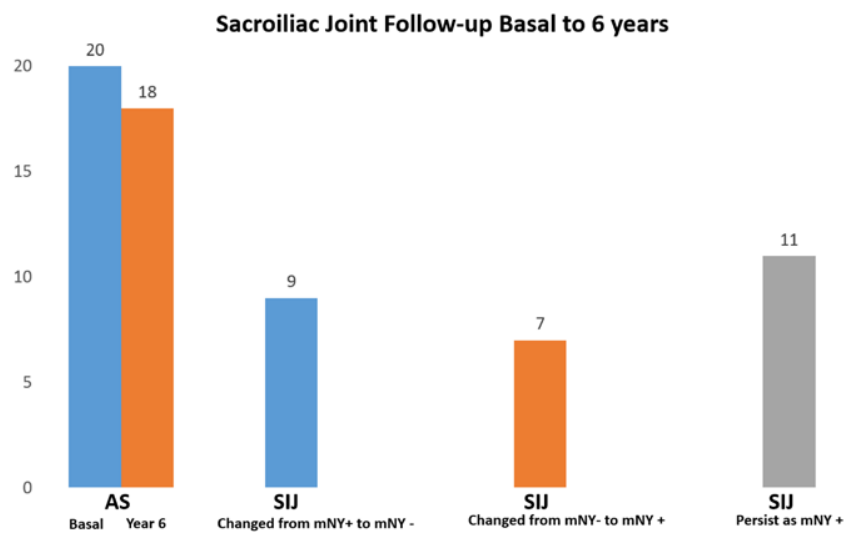

Disclosure of Interests: Carolina Tornero: None declared, María del Carmen Castro Villegas: None declared, Xavier Juanola-Roura: None declared Maria Luz García-Vivar: None declared, Cristina Fernández-Carballido Consultant of: Yes, I have received fees for scientific advice (Abbvie, Celgene, Janssen, Lilly and Novartis), Speakers bureau: Yes, I have received fees as a speaker (Abbvie, Celgene, Janssen, Lilly, MSD, Novartis), Jose Francisco Garcia LLorente: None declared, Beatriz Joven-Ibáñez Speakers bureau: Abbvie, Celgene, Janssen, Merck Sharp \& Dohme, Novartis, Pfizer E. Galindez: None declared, Claudia Urrego-Laurín: None declared, Eugenio de Miguel Grant/research support from: Yes (Abbvie, Novartis, Pfizer), Consultant of: Yes (Abbvie, Novartis, Pfizer), Paid instructor for: yes (AbbVie, Novartis, Pfizer, MSD, BMS, UCB, Roche, Grunental, Janssen, Sanofi), Speakers bureau: yes (AbbVie, Novartis, Pfizer, MSD, BMS, UCB, Roche, Grunental, Janssen, Sanofi)

DOI: 10.1136/annrheumdis-2020-eular.5450

\section{\begin{tabular}{|l|l|l|}
\hline FRI0325 UVEITIS OCCURRENCE IN EARLY INFLAMMATORY \\
\hline
\end{tabular} BACK PAIN. FIVE YEARS DATA FROM A PROSPECTIVE FRENCH NATIONWIDE COHORT}

D. Wendling ${ }^{1}$, C. Prati $^{1}$, T. Lequerre ${ }^{2}$, C. Miceli Richard ${ }^{3}$, M. Dougados ${ }^{3}$, A. Moltó ${ }^{3}$, X. Guillot ${ }^{4}$. ${ }^{1} \mathrm{CHU}$, University Teaching Hospital, Rheumatology, Besançon, France; ${ }^{2} \mathrm{CHU}$, University Teaching Hospital, Rheumatology, Rouen, France; ${ }^{3}$ Cochin Hospital, Rheumatology, Paris, France; ${ }^{4} \mathrm{CHU}$, University Teaching Hospital, Rheumatology, Saint denis de la Réunion, Reunion Island

Background: Uveitis is the most frequent extra rheumatological manifestation in axial Spondyloarthritis (SpA). DESIR is a prospective multicenter cohort of patients with early inflammatory back pain suggestive of SpA. We reported previously a $8.5 \%$ baseline prevalence of uveitis for the patients included in the cohort; this history of uveitis at the first visit of the cohort was associated with inflammatory bowel disease (IBD) and preceding infection (1).

Objectives: The aim of the study was to evaluate the prevalence and incidence of uveitis over the first five years of prospective follow-up of the cohort, and to evaluate its associated factors.

Methods: DESIR is a prospective observational cohort of patients with recent onset inflammatory back pain (more than 3 months, less than 3 years), suggestive of axial SpA, All available factors in the database were compared between patients with and without uveitis at 5 years, by uni and then multivariate analysis. Baseline factors associated with new cases of uveitis occurrence over the 5 years were also analyzed. Significance: $p$ less than 0.05 .

Results: After 5 years, 91 patients (out of 480 with complete follow-up) had at least one uveitis episode, giving an estimated prevalence of $18.9 \%[95 \% \mathrm{Cl}$ : $15.4-$ 22.4]. In multivariate analysis, uveitis was associated with dactylitis (OR 2.92 $\left.[2.06-4.14] ; p=0.002^{\star \star}\right)$, ESR > 7mm (median value) (OR $2.19[1.57-3.06]$ $\left.\mathrm{p}=0.018^{*}\right)$.

New incident uveitis occurred in 31 cases over 5 years, giving an estimated incidence rate of 1.29 [0.84 - 1.74] / 100 patient-years. New incidence of uveitis was 